\title{
DEFORMITY IN THE ROMAN IMPERIAL COURT*
}

Over the past two decades, the study of deformity and disability in the ancient world has stimulated intense scholarly debate. ${ }^{1}$ Recognizing a relatively unexplored body of ancient evidence, scholars have sought to reintegrate the anomalous human body (placed rather unceremoniously under the broad category of 'Other') into the (art-) historical record, classical scholarly consciousness, and our understanding of ancient representation more broadly. This article works towards that end, considering the representation of deformity as documented in extant literary sources of the Roman world. It will employ the hunchback as linchpin, since the figure of the hunchback has remained essentially outside this (albeit still developing) field of research. ${ }^{2}$

To begin, we must turn to the issue of terminology. In antiquity there was no clear distinction between a deformity and a disability, nor were there any precise Greek or Latin equivalents to these modern designations. ${ }^{3}$ Nevertheless, the ancients did have an extensive vocabulary to describe various aspects of deformity and disability. In Latin

\footnotetext{
* This article is based on a chapter of my doctoral thesis. I am indebted to my supervisor, Dr Caroline Vout, for her guidance in shaping its original form. Versions of this paper were delivered at the Annual Meetings of the Classical Associations of Canada and the UK. For the comments and insights from the audiences on both of these occasions, I am most grateful. Sincere thanks also to the anonymous readers at Greece and Rome for their recommendations towards its publication here. All translations are my own.

${ }^{1}$ Paving the way was Robert Garland's seminal work, The Eye of the Beholder. Deformity and Disability in the Graeco-Roman World (first published Ithaca, NY, 1995; second edition with preface and supplementary bibliography, London, 2010), which offers a wide-ranging investigation of disabled and deformed people in the ancient world through a variety of discursive modes, including literary, artistic, and medical. Garland's work spurred a number of subsequent studies in the field. These included a special issue of Arethusa dedicated to Vile Bodies. Roman Satire and Corporeal Discourse (1998), and Martha Rose's, The Staff of Oedipus. Transforming Disability in Ancient Greece (Ann Arbor, MI, 2003). Most recent is the edited volume by H. Avalos, S. Melcher, and J. Schipper, This Abled Body. Rethinking Disabilities in Biblical Studies (Atlanta, GA, 2007) which includes a very informative chapter (pp. 31-46) on 'Deformity and Disability in Greece and Rome' by Nicole Kelley.

${ }^{2}$ Continuing work by the author has attempted to put the figure of the hunchback back on the map, so to speak, and to give these representations the attention that they have hitherto been denied. See L. Trentin, 'Re-presenting Deformity in Greco-Roman Art' (unpublished PhD thesis, University of Nottingham, 2007) and 'What's in a Hump? Re-examining the Hunchback in the Villa Albani-Torlonia', CCf (2009), 130-56.

${ }^{3}$ The modern categories identified by the terms 'deformed' and 'disabled' are not mutually exclusive. As Garland (n. 1), 5 notes, 'no absolute distinction exists between a deformity, which we may define as a deviation from normal appearance, and a disability, which, whether or not it is the result of a deformity, produces a malfunction'.
} 
there exists a wide range of stock terms used to denote an individual whose form deviated from the 'normal' Roman somatic type. The words deformis, deformitatus, distortus, retortos, and informis are often used interchangeably to describe individuals with unusual (or ugly) physical features and/or obvious physical deformities. These individuals ranged from the more mundane, everyday emaciated men and obese women to the prodigious hermaphrodites, dwarfs, hunchbacks, and eunuchs. In many cases, these terms only take on specific meaning in the individual contexts in which they are used. The terminology itself thus becomes secondary to context, which is highly informative of attitudes towards the deformed and their treatment in society.

References to deformed individuals in the extant literary sources appear in a wide array of contexts, from medical texts to imperial biographies, from the third century BCE to the fourth century CE. Although eclectic in terms of genre and chronology, these sources demonstrate that deformed individuals featured prominently as companions and entertainers of the elite, especially within the Roman imperial court. Various sources suggest that many Romans prized deformed slaves; however, it was the relationship between the emperors and their deformed slaves that was of particular interest to ancient authors and readers alike. This article will examine these relationships as represented primarily in the imperial biographies of Suetonius and the Scriptores Historiae Augustae (hereafter SHA), since they provide the most copious 'evidence' for these relationships. Its focus is not on the historical nature of such relationships, since the dubious credentials of both sources are well attested, ${ }^{4}$ but rather on the implications of their representation, particularly how they are used by the ancient authors to say something about the emperor, courtly society, and the construction of imperial power. Unavoidably, the analysis that follows will rely on the distinction between the socalled 'good' and 'bad' Roman emperors inasmuch as these categories form part of a literary trend schematizing the emperors politically and morally. As shall be demonstrated, it is the very existence of deformed individuals within the imperial court and their metaphorical political value that contributed to the schematization of the 'bad' emperor.

\footnotetext{
${ }^{4}$ The $S H A$ in particular is now normally considered to be a largely fictive text. See R. Syme, Emperors and Biography (Oxford, 1971) and idem, The Historia Augusta. A Call for Clarity (Bonn, 1971), alongside D. Paunch, 'Unreliable Narration in the Historia Augusta', Ancient Narrative 8 (2010), 115-36 and D. Burgerdijk, 'Style and Structure of the Historia Augusta' (unpublished $\mathrm{PhD}$ thesis, University of Amsterdam, 2010).
} 


\section{Displaying the deformed body}

In ancient Rome, deformed individuals were regularly displayed for popular entertainment, part of a well-established tradition of displaying the anomalous body (both human and animal) in Roman culture. The Elder Pliny records that the bones of Pusio and Secundilla, the tallest people alive in the reign of Augustus, were preserved in Sallust's Gardens in Rome because of their height, an extraordinary nine and a half feet tall. ${ }^{5}$ At the opposite extreme, Suetonius reports that Augustus once exhibited a dwarf named Lycius, who was less than two feet tall and weighed a mere seventeen pounds. ${ }^{6}$ Suetonius also informs us that, if anything rare or noteworthy was brought into Rome, Augustus was in the habit of making it available for public display; moreover, he is even said to have decorated the rooms of his villas with such objects, especially those noteworthy for their age and rarity. ${ }^{7}$ In Augustan Rome, it appears that anomalous bodies of all sorts were a conventional interest of the populace, made available by the benefaction of the emperor himself. ${ }^{8}$

Against such a background, it is not surprising that the literature of the imperial period also suggests that wealthy Romans, too, sometimes prized individuals with unusual physical features and obvious physical deformities. Plutarch states that in Rome the demand for deformed slaves was so great that monster markets ( $\tau \hat{\omega} \nu \tau \epsilon \rho \alpha ́ \tau \omega \nu$ á $\gamma o \rho \dot{\alpha} \nu$ ) emerged where persons who 'have no calves, or who are weasel-armed or who have three eyes or who are ostrich-headed' could be purchased. ${ }^{9}$ Quintilian also claims that deformed slaves were in such demand that some Romans were prepared to pay more for them than for physically perfect ones. ${ }^{10}$ The apparent obsession for owning deformed slaves becomes disturbing, however, when we hear of individuals being deliberately disfigured. Longinus reports that slaves could be bound and confined in cages, known as glottokomae, in order to stunt their growth and thus dwarf them. ${ }^{11}$

\footnotetext{
${ }^{5}$ Plin. HN 7.75 ff.

${ }^{6}$ Suet. Aug. 43.3.

${ }^{7}$ Ibid., 43.4 and 72.3. For collections of bizarre human anatomy in antiquity, see L. Casson, Travel in the Ancient World (London, 1974), 244-6.

${ }^{8}$ Augustus, however, is not stigmatized for this. Suetonius goes so far as to reassure the reader that Augustus himself 'shunned dwarfs, the deformed, and all things of that kind as evilomened mockeries of nature' (Suet. Aug. 83). This will be discussed further below.

${ }^{9}$ Plut. Mor. 520c.

${ }^{10}$ Quint. Inst. 2.5.11.

${ }^{11}$ [Longinus], Subl. 44.5.
} 
Although this evidence suggests that the popularity of deformed slaves was widespread, it was the Roman emperors who are said to have had a particular predilection for them. ${ }^{12}$ Their relationship warranted a recurrent discourse not only in imperial biography but in ancient sources more generally. So why did ancient authors think and write about this in antiquity? To answer this question it is necessary to turn to those emperors who are schematized by the ancient sources as categorically 'bad'. In the literary sources, deformed individuals and other unsavoury types are routinely (and in Suetonius' Lives and the $S H A$ almost exclusively) paired with the bad emperors to provide evidence for a greater moral decay in their regimes; they become, in effect, mirrors of the emperor's own 'constitutional, social and amoral uniqueness'. ${ }^{13}$

In the imperial biographies of Suetonius and the $S H A$ the bad emperors are invariably depicted as 'monstrous', a term that not only denotes a monster or atrocity in the strictest sense but also an omen or portent of atrocities to come. ${ }^{14}$ As Braund and James note, "The concept of "monstrosity" covers a considerable range of physical, moral, and, by extension, political ideas in Roman thought, with a clear notion of something unnatural, deformed, or prodigious which readily shades into the realm of the barbaric and the bestial. ${ }^{15}$ Because they stood outside the social environment over which they ruled, the bad emperors alone were able to indulge their monstrous appetites. Indeed, these monstrous appetites served to underline their own position as 'Other' and could be used to demonstrate how easily one could transgress the boundaries of 'Self' and 'Other', man and monster. ${ }^{16}$ The analysis that follows will thus begin by examining the monstrosity of the bad emperors, that is, the means by which they are

${ }^{12}$ Garland (n. 1), 46 goes so far as to say that 'It would almost seem as if no fashionable household was complete without a generous sprinkling of dwarfs, mutes, eunuchs and hunchbacks.'

${ }^{13}$ Ibid., 45.

${ }^{14}$ For the link between emperor and monster, see K. Hopkins, Conquerors and Slaves (Cambridge, 1978), 118-23 and Garland (n. 1), 50-2. For the concept of monstrosity and its definition and role in Greece and Rome more generally, see C. Atherton, Monsters and Monstrosity in Greek and Roman Culture (Bari, 2000).

${ }^{15}$ S. M. Braund and P. James, in S. M. Braund and B. K. Gold (eds.), Vile Bodies. Roman Satire and Corporeal Discourse, Arethusa 31.3 (Baltimore, MD, 1998), 288.

${ }^{16}$ Making these men/monsters interstitial figures. Mary Douglas' pioneering work, Purity and Danger. An Analysis of Concepts of Pollution and Taboo (New York, 1969), introduces the idea of interstitial figures - creatures that fall somehow between those categories that we generally use to structure our environment or partake of more than one such category, and are thus looked upon as particularly powerful, sacred, or dangerous - or a combination of the three. 
represented as sub- or non-human. This is manifested in three ways: first, in their physical appearance; second, in their actions, particularly the way that they treat their inferiors; and third, in the company that they keep; all of which had equally powerful ethical and political significance.

\section{The Roman emperor as monster}

Of the Roman emperors schematized as categorically 'bad', this article will focus on the emperor Commodus, for it is in the $S H A$ 'Life of Commodus' that all of the characteristics of the monstrous emperor are to be found, clearly linking Commodus to a monstrum. ${ }^{17}$ The reader is repeatedly informed of Commodus' ugly appearance, his incorrigible abuses of power, his ill-treatment of friends and foes, and the questionable characters with whom he associates. It is clear that the author of the $S H A$ was writing in the tradition of Roman invective rhetoric, highlighting the abominable habits of the emperor as evidence of his aberrant and transgressive status. Whether these stories were in fact true, however, is another matter altogether. Although now normally considered to be a largely apocryphal text, the $S H A$ is nevertheless informative for the insight that it offers readers (both ancient and modern alike) into the workings of the imperial court, and the idiosyncrasies and aberrations of its rulers. Reading the $S H A$ is not a simple matter of deciphering fact from fiction, though perhaps it is a problem of historiography. Fortunately, however, it is of hardly less historical significance to know what bad emperors could be believed capable of than to know what they did or did not actually do. With that fundamental proviso, this article will examine the relationship between emperors and deformed individuals for their representation, contextualized within the texts of imperial prose biography.

In the account of the 'Life of Commodus' in the $S H A$, Commodus is presented as a monstrum. This portrayal is in keeping with the attitude displayed by many ancient authors towards the bad emperors; it is part of an established tradition of discourse that divides good

${ }^{17}$ Three extant texts recount the 'Life of Commodus'. Cassius Dio is perhaps the most contemporary source (164-229 CE), followed by Herodian (175-260 CE) and then the SHA. O. Hekster, Commodus. An Emperor at the Crossroads (Amsterdam, 2002), 8, notes that 'all three biographers present the emperor as a stereotypically bad emperor'. 
emperors and tyrants. Good emperors are likened to divinities and thus look and act 'god-like' while tyrants are likened to monstra and thus look and act 'deformed'. Suetonius, before describing the contemptible acts of Caligula, states, 'This much has been said about Caligula as emperor; it remains to be told about Caligula the monster [de monstro]'. ${ }^{18}$ Seneca, in his Apocolocyntosis, presents Claudius in a similar fashion, recognized by Hercules not as the emperor but as a possible monster (monstra) and a quasi homo. ${ }^{19}$ These men are morally and metaphorically monstrous as much as they are physically monstrous. Caligula is said to have had an irregular body, an ugly face, and a bald head. ${ }^{20}$ Claudius' strange appearance, weird walk with dragging right foot, and hoarse, incomprehensible voice makes Hercules, the monster-slayer, believe that his thirteenth labour has arrived.

The authority and reputation of an emperor was thus located in his body and his physical integrity. This is true of both good and bad emperors but was manipulated accordingly. For example, although Augustus and Nero are both described as having corpora maculosa (spotted bodies), Nero's spotted body is foul (fetido); Augustus' spotted body, on the other hand, is somehow otherwordly, for his spots were 'scattered about his breast and belly in form, order, and number as the stars of the Great Bear in the heavens'. ${ }^{21}$ Similarly, both Caligula and Julius Caesar are said to have suffered from baldness (capillo raro). ${ }^{22}$ Caligula's baldness suggests a deeper mental and moral abnormality, since we are told by Suetonius that Caligula pronounced it a crime meriting death if, when he was passing, anyone should look down on him from above. ${ }^{23}$ Julius Caesar's baldness, however, exposed his divine integrity, since Suetonius states that, of all the honours he received from the Senate and the Roman people, none did Caesar accept or take advantage of more willingly than his right to wear a laurel wreath

${ }^{18}$ Suet. Calig. 22.1.

${ }^{19}$ Sen. Apocol. 5.1-3. For a detailed analysis of the emperor Claudius as a physical monster, see Braund and James (n. 15), 285-311.

${ }^{20}$ Suet. Calig. 50.1.

${ }^{21}$ Suet. Ner. 51.1; Suet. Aug. 80.1.

${ }^{22}$ Baldness was considered a mild deformity in antiquity, one that affected many emperors and greatly distressed several of them. For the satirization of baldness, see Mart. Epigr. 5.49, 6.57, 10.83. For further reading, see L. Morgan, 'Achilleae Comae: Hair and Heroism According to Domitian', $C Q 47$ (1997), 209-14; D. Woods, 'Caligula, Ptolemy of Mauretania, and the Danger of Long Hair', Arctos 39 (2005), 207-14.

${ }^{23}$ Suet. Calig. 50.1. 
at all times. ${ }^{24}$ In these examples, the same physical features - spotted bodies and bald heads - are manipulated to reflect the authority and reputation of the emperor. All bad emperors are thus deformed in some way, shape, or form. ${ }^{25}$ These physical traits serve as outward signs of an immoral character, as suggested by extant physiognomic treatises. ${ }^{26}$ More than this, they serve as markers of 'Otherness' and set these emperors against the kalos kagathos (beautiful and good) type.

The bad emperors are represented as monstrous not only in their appearance but also in their actions. Part of the standing charge against such emperors was their incorrigible abuse of power to manufacture deformity, either as punishment or merely for the purpose of their own idle amusement and that of Suetonius' and the SHA's readers. Here also, the 'Life of Commodus' reveals the emperor's monstrosity. We are told that Commodus, even in his humorous moments, was destructive. One corpulent man he cut open down the middle of his belly so that his intestines gushed forth. Other men he dubbed oneeyed or one-footed, after he himself had plucked out one of their eyes or cut off one of their feet. ${ }^{27}$ Many other emperors are reproached because of their cruel and unusual behaviour towards their inferiors. Suetonius states that, at a public banquet in Rome, Caligula is said to have had a slave's hands cut off, hung around his neck, and paraded among the guests, as punishment for having stolen a strip of silver. ${ }^{28}$ Caligula is also said to have disfigured (deformatos) with marks of branding irons the bodies of many men of honourable rank. ${ }^{29}$ Tiberius also, in his moments of paranoia, could be brutal. In one story recounted by Suetonius, Tiberius is said to have had the face of a fisherman mangled (lacerari) with a lobster. ${ }^{30}$ To be touched by these emperors left one not honoured but scarred. Just as the ideal emperor was thought to be a moral exemplum to his subjects, the bad emperor was thought to be a warning sign; by 'playing god' he could turn any one of his subjects into visual proof of his own inhumanity.

Beside creating monstrosity, the bad emperors could handpick their own monsters. Indeed, the notion of the monstrous emperor is

\footnotetext{
${ }^{24}$ Suet. $\mathrm{ful}$. 45.2 . He is also said to have attempted to disguise his baldness by combing his scanty hair forward from the crown.

${ }^{25}$ See Suet. Tib. 68, Ner. 51, Galb. 21.1, Vit. 17, Dom. 18.2.

${ }^{26}$ See, Polemo, de Physiognomonia 1.210, 7-12; Adamantius, Physiognomonica 1.361, 5-362, 2; Anonymous Latin author, de Phsiognomonia 112 and 71.

${ }^{27}$ SHA, Comm. 10.4-5.

${ }^{28}$ Suet. Calig. 32.2.

${ }^{29}$ Ibid., 27.

${ }^{30}$ Suet. Tib. 60 .
} 
further manifested in the monstrous bodies with which he surrounded himself, including deformed people. These deformed individuals are often described as emphatically foul and ugly, and they often acted as informers or spies, confidants, or intimate lovers of the emperor, further exaggerating their contemptible nature and reflecting that of the emperors. ${ }^{31}$ These individuals are thus flagged as persons associated with immorality and perversion, highlighting those same characteristics in the emperors who exploited them.

One of the main occasions in which an emperor could display his own handpicked monsters (and thus his position of power) was the Roman banquet. ${ }^{32}$ These operated as vehicles for the display of an emperor's virtues, opportunities for the emperor to reveal to his subjects how he exemplified the necessary qualities of a good ruler. The feasts of the bad emperors, however, represented the very antithesis of those of a good emperor, since they promoted not virtue but vice. ${ }^{33}$ At the banquets of the bad emperors, the principal duty of deformed individuals appears to have been to undergo degrading displays of humiliation in order to provide amusement and entertainment. This practice may be traced as far back as the episode in the Iliad where the lame god Hephaistos features in an Olympian feast, making the gods laugh on account of his wine-pouring antics, although whether they laugh with him or at him is debated. ${ }^{34}$ That deformed individuals were funny to look at is suggested by several ancient authors, including Cicero and Quintilian, who state that they were ideal subjects for ridicule and derision. ${ }^{35}$ This probably resulted in deformed individuals performing as entertainers from the Hellenistic period onwards. ${ }^{36} \mathrm{We}$ are told that the emperor Elagabalus was in the habit of inviting to his banquets eight bald men, eight one-eyed men, eight men with

${ }^{31}$ For specific examples, see Suet. Dom. 4.2; Juv. Satire 4.116; Tac. Ann. 12.49.1.

${ }^{32}$ On the Roman banquet, see esp. W. J. Slater, Dining in a Classical Context (Ann Arbor, MI, 1991) and K. Dunbabin, The Roman Banquet. Images of Conviviality (Cambridge, 2003).

${ }^{33}$ J. Goddard, 'The Tyrant at Table', in J. Elsner and J. Masters (eds.), Reflections of Nero (London, 1994), 67-81.

${ }^{34}$ Hom. Il. 1.599-600. W. Burkert, Greek Religion (Cambridge, 1985), 168, and C. G. Brown, 'Ares, Aphrodite, and the Laughter of the Gods', Phoenix 43 (1989), 287, suggest that Hephaistos intended to provoke the laughter, thus the gods laugh with him; Garland (n. 1), 79, however, sees it as the gods laughing at him.

${ }^{35}$ Cic. De or. 2.239; Quint. Inst. 6.3.7.

${ }^{36}$ The evidence for dwarfs as entertainers is especially compelling. See the multiple works by V. Dasen, including Dwarfs in Ancient Egypt and Greece (Oxford, 1993) and 'L'Enfant qui ne grandit pas', Medicina nei secoli 18.2 (2006), 1-13, as well as M. Garmaise, 'Studies in the Representation of Dwarfs in Hellenistic and Roman Art' (unpublished PhD thesis, McMaster University, 1996). 
gout, eight deaf men, eight black men, eight tall men, or eight fat men, simply to provoke laughter at all of them. ${ }^{37}$ Elagabalus is also accused of having had so many deformed persons, including dwarfs and eunuchs (nanos et nanas...et...eunuchos), in his immediate retinue that his successor, Alexander Severus, disposed of the entire troop for fear that they would exhaust his treasury. ${ }^{38}$ But when did such displays become degrading or humiliating? An interesting line from the 'Life of Commodus' may help elucidate this. During part of a long diatribe against the emperor's monstrous habits, the reader is told that Commodus displayed at a private banquet two misshapen hunchbacks, served on a silver platter and smeared with mustard. ${ }^{39}$

It may not be presumptuous to devote a few pages to the scrutiny of this brief statement, given the multiple readings that can be derived from the $S H A$ and the peculiarity of the event itself. Moreover, the use of the hunchback's body in this passage, as a dish to be served like any other, gives us food for thought to examine how these figures function within the text - in what they can reveal not only about imperial power and the bad emperors but also about the display of the body of the 'Other' for derision and entertainment.

\section{Commodus serves two hunchbacks}

In the statement above, the body of the hunchback is served as a display piece, one of the methods of display being as a foodstuff. There has been a significant amount of work on the representation of food in antiquity. ${ }^{40}$ From this, it has been amply demonstrated that food and the body were clearly linked, not only because it was through the body that food was consumed and absorbed but also because food had a vast potential for projecting an individual's moral and cultural values. ${ }^{41}$ It was certainly used in this way to describe the Roman emperors. For example, according to Suetonius, Augustus was extremely frugal and liked to eat plain food, such as coarse bread. ${ }^{42}$ His physical shape was

${ }^{37}$ SHA, Heliogab. 29.3.

${ }^{38}$ SHA, Alex. Sev. 34.2-4.

${ }^{39}$ SHA, Comm. 11.1. 'duos gibbos retortos in lance argentea sibi sinapi perfusos exhibuit eosdemque statim promovit ac ditavit'.

${ }^{40}$ See esp. N. Hudson, 'Food in Roman Satire', in S. Braund (ed.), Satire and Society in Ancient Rome (Bristol, 1989), 69-87; E. Gowers, The Loaded Table. Representations of Food in Roman Literature (Oxford, 1993); Goddard (n. 33), 67-81.

${ }^{41}$ Gowers (n. 41), 4.

${ }^{42}$ Suet. Aug. 76. 
indicative of his frugality: he was short and slight. ${ }^{43}$ Vitellius, on the other hand, had a boundless appetite and would, even when he was sacrificing or making a journey, snatch bits of meat and cakes amid the altars and in the cook shops along the road, devouring them on the spot. ${ }^{44}$ His physical shape was indicative of his gluttony - he had a huge, rounded belly. ${ }^{45}$ What the emperor ate, and moreover how he ate it, was highly indicative of how he ruled his empire. The statement in the Commodus passage seems to be playing with the question of 'can we eat it?' and the issue of the body as food and the emperor as consumer.

Commodus displayed (exhibuit) two hunchbacks on a silver platter smeared in mustard. The usage of exhibere is deliberately ambiguous: literally, it means to present or exhibit, but it is also a standard term for serving food. ${ }^{46}$ The hunchbacks are, on one level, simply a centrepiece, an entertaining accompaniment to the meal of the banquet; however, the fact that they are smeared in mustard complicates their visual display. The mustard with which these hunchbacks are covered is important in three respects. First, mustard is an ingredient whose agreeableness is compromised by its acidic quality. ${ }^{47}$ The evidence for this is borne out by a passage in Plautus' Pseudolus, in which mustard is described as a vicious plant (sinapis scelera) so acerbic that it stings the eyes (triverunt oculi) of anyone who grates it. ${ }^{48}$ In Aristophanic comedy, mustard is also used in expressions of the types of glances that make viewers feel uncomfortable. ${ }^{49}$ This begs the question: does looking at these poor hunchbacks smeared in mustard sting the eyes of the banqueters watching? In this example, the mustard is designed to stress the eye-watering nature of this odd and humiliating display.

Second, one must remember that mustard is a condiment, a relish or seasoning for food. These hunchbacks are alive and are certainly not intended to be eaten. Commodus' display of the hunchback as a makeshift meal is part of a long established tradition of serving fake and inedible food. In the Cena Trimalchionis of Petronius, we are introduced to 'fake dinners' (cenarum imagines) that were produced

\footnotetext{
${ }^{43}$ Ibid., 79.

${ }^{44}$ Suet. Vit. 13.3.

${ }^{45}$ Ibid., 17.

${ }^{46}$ C. T. Lewis and C. Short, A Latin Dictionary (Oxford, 1879), 685.

${ }^{47}$ Gowers (n. 41), 98.

${ }^{48}$ Plaut. Pseud. 817-18.

${ }^{49}$ See Ar. Eq. 631, Ach 254, Vesp. 455, Ran. 603, Eccl. 292.
} 
at the Saturnalia in Rome..$^{50}$ In a Saturnalian context, the serving of fake and inedible food is in keeping with the variations of the usual patterns of eating; however, when taken out of context this practice becomes symbolic of the monstrous appetite of a bad emperor. ${ }^{51}$ Indeed, serving inedible food is a common practice at the banquets of the bad emperors. Perhaps the best (or worst) example of this is Elagabalus, who, we are told, often served

meals made of wax, or wood, or ivory, sometimes of earthenware, and sometimes either of marble or stone, so that all of his guests would be served that which he ate, but of a different material and only to be looked at. ${ }^{52}$

The fact that such displays were intended only to be looked at (videnda) emphasizes the display of the hunchbacks in the Commodus passage, qualifying and legitimizing our looking at them. But it also suggests an oscillation between whether these hunchbacks are good to look at (or not) and whether their display is good (or not). The line preceding this adds to the play on serving edible and inedible food: we are told that Commodus also enjoyed mixing human excrement with the most expensive of foods and did not refrain from tasting them. ${ }^{53}$ The implication of this is that we might start to see these hunchbacks as excrement too, until we hear that the emperor promotes them by making them rich (ditavit). They are not alone. Two lines prior, we also hear that Commodus has in his company a man with a male member larger than that of most animals, whom he duly called Onos, and that he made him rich (ditavit) and promoted him to the priesthood of the Rural Hercules. These abnormal and deformed individuals functioned not only as display pieces but as displays of the emperor's erratic and disturbed behaviour. They became transgressive anomalies, interstitial figures who crossed the boundary between monster and man, considered at once filthy and filthy rich.

Finally, the fact that these hunchbacks were covered in mustard perhaps also played upon an ancient superstition that rubbing the hump of the hunchback was considered good luck. Are these golden

${ }^{50}$ Petron. Sat. 69.9.

${ }^{51}$ Some bad emperors were 'Saturnalian' all the time; Claudius, for example, in Seneca's Apocolocyntosis (8.2), is described as Saturnalicius princeps. For the Saturnalian rule of an emperor, see H. S. Versnel, 'Two Carnivalesque Princes: Augustus and Claudius and the Ambiguity of Saturnalian Imagery', in S. Dopp (ed.), Karnevaleske Phänomene in antiken und nachantiken Kulturen und Literaturen (Trier, 1993), 99-122.

${ }^{52}$ SHA, Heliogab. 25. See also ibid., 27, for additional examples.

${ }^{53}$ SHA, Comm. 10.9. 
hunchbacks bearers of fortune for anyone who might venture to get their hands dirty? ${ }^{54}$ Whatever the case, the point is certainly this: one cannot look at (let alone touch) these hunchbacks without being implicated in their display, and that implication can play out in a number of ways.

To further contextualize the display of the hunchbacks in the Commodus passage, we might turn to an interesting story about a hunchback mentioned by Pliny the Elder. ${ }^{55}$ In his Natural History, Pliny recounts the story of a wealthy woman named Gegania who receives a free hunchback slave named Clesippus with her purchase of a very expensive Corinthian chandelier. Showing off her purchases at a dinner party (in convivio), Gegania has her new slave appear naked (nudatus) to entertain her guests. During his performance, Gegania is said to have developed a shameless desire (impudentia libidinis) for the hunchback, admitting him to her bed and then later giving him a place in her will, after which he became excessively rich. Pliny also states that, when Gegania died, Clesippus is said to have erected a noble tomb to commemorate (and thus forever shame) his mistress. ${ }^{56}$

On account of its positioning within the text of book 34, 'The Natural History of Metals', Pliny's anecdote can be read primarily as an account of the high prices paid for Corinthian bronze chandeliers; however, it also serves as a commentary on the exhibition and display of the deformed body, the hunchback in particular, for entertainment purposes within the context of the banquet. What is interesting in this story is the fact that Clesippus is no ordinary hunchback. Pliny states that not only is he of a foul appearance (foedus aspectu) but he is also a fuller, a man whose principal duty was to launder clothes using,

\footnotetext{
${ }^{54}$ According to modern superstition in Italy and the Mediterranean, rubbing the hump of a hunchback is considered good luck, a custom that seems to have derived from ancient superstition. See esp. F. T. Elworthy, The Evil Eye. An Account of This Ancient and Widespread Superstition (London, 1895); A. J. B. Wace, 'Grotesques and the Evil Eye', ABSA 10 (1903/4), 103-14; C. Maloney, The Evil Eye (New York, 1976).

${ }^{55}$ Plin. HN 34.6.

${ }^{56} \mathrm{~A}$ limestone titulus, originally found in the Pomptine marshes, survives today on the wall of a modern building on the Via Appia, south of Rome near Tarracina, bearing the name Clesippus Geganius [CIL 1(2) 1004]:
}

Clesipus Geganius, Mag[ister] Capi[tolinus], mag[ister] Luperc[orum], viat[or] tr[ibunicius]

The titulus measures three metres in length and dates from the last years of the Republic, based on orthography and lettering. Although Pliny does not date his anecdote, and it is uncertain whether the surviving inscription came from the tomb mentioned by Pliny, it has been argued that the two Clesippi are one and the same. See J. Bodel 'Trimalchio and the Candelabrum', CPh 84 (1989), 224-31. 
among other 'detergents', human urine.$^{57}$ Gegania's desire for such a polluted creature adds to her impudentia and thus serves to highlight her own 'Otherness'. Like the hunchbacks in the Commodus passage, Clesippus is a transgressive anomaly who crosses the boundary between monster and man, a filthy and filthy rich creature. Moreover, Clesippus becomes a testament to the constitutional, social, and amoral uniqueness of Gegania, just as the hunchbacks in the Commodus passage reflect that of the emperor.

\section{Beyond the bad emperors}

The evidence examined thus far clearly suggests that the relationship between the bad Roman emperors and their deformed slaves was a way of encoding the abnormal moral and political status of the emperor. This, however, is only part of the picture, for it was not just the bad emperors who were represented as having relationships with deformed individuals. Although Suetonius would have his readers believe that good emperors, such as Augustus, 'shunned dwarfs, the deformed, and all things of that kind as evil-omened mockeries of nature', ${ }^{58}$ other sources relate that even he owned a deformed jester named Gabba, and gave as a gift to his granddaughter Julia a dwarf named Conopas. ${ }^{59}$ This suggests that deformed individuals featured within the imperial courts of emperors who were not normally typecast as bad. Clearly, the function of these figures within courtly society is considerably more complicated than their use as mere scapegoats upon which to peg the aberrant rule of an emperor. Indeed, the relationship between the emperors and individuals possessing physical deformities - two polarities in the social spectrum, the debased and the exalted, in a society where the differential between these two groups pervaded all aspects of Roman political, social, and ethical ideologies - is perhaps better explained by the fact that both were considered social anomalies and operated within categories outside the social constructions of normality, thus inevitably gravitating towards one another.

${ }^{57}$ Plin. HN 35.49 and 35.57 discuss the ingredients and processes of cleaning employed by the fuller. On the fuller's craft, see R. J. Forbes, 'Washing, Bleaching, Fulling and Felting', Studies in Ancient Technology 4 (1956), 86-8.

58 Suet. Aug. 83.

${ }^{59}$ Plut. Mor. 726a; Plin. HN 7.75. 


\section{Conclusion}

This article has examined the relationship between the Roman emperors and their deformed slaves as represented in the imperial biographies of Suetonius and the $S H A$, using the emperor Commodus as an extreme case in the Roman-emperor-as-monster link. It has thus demonstrated that the bad Roman emperors often exhibited their deformed slaves in debasing and humiliating contexts so as to provide amusement and entertainment, as highlighted by Commodus' display of two hunchbacks smeared in mustard at a banquet.

The idea of displaying deformed individuals for amusement or entertainment is perhaps disturbing to a modern reader (or viewer); however, it must be acknowledged that this phenomenon also existed in the modern era. The ancient practice is comparable to that of the nineteenth-century American and European fascination with sideshows, dime museums, and circuses. The formally organized exhibition of people with physical, mental, or behavioural anomalies was especially popular from 1840 to 1940 and commonly referred to as the 'Freak Show' ${ }^{60}$ Although figures such as the dwarf and the hunchback had become less popular, the new 'freaks' of the time were strongly reminiscent of the deformed in antiquity: fat ladies, bearded ladies, living skeletons, hermaphrodites, spotted boys, giants, and Siamese twins. As Adams notes, the sideshow platform was 'both a source of entertainment and a stage for playing out many of the century's most charged social and political controversies...the freak show maps anxieties and fantasies that underpin collective responses to contemporary events' ${ }^{61}$ In the same way, the relationship between the bad Roman emperors and their deformed slaves gave ancient historians a convenient peg on which to hang historical causes.

LISA TRENTIN

ltrentin@wlu.ca

${ }^{60}$ On the 'Freak Show', its history, and allure, see L. Fiedler, Freaks. Myths and Images of the Secret Self (New York, 1978); R. Bogden, Freak Show. Presenting Human Oddities for Amusement and Profit (Chicago, 1988); R. G. Thompson, Freakery. Cultural Spectacles of the Extraordinary Body (New York, 1996); R. Adams, Sideshow U.S.A. Freaks and the American Cultural Imagination (Chicago, IL, 2001).

${ }^{61}$ R. Adams (n. 63), 2-3. 